International Journal of Child, Youth and Family Studies (2012) 2 \& 3: 316-330

\title{
THE QUESTION OF DOORS
}

\author{
Hans Skott-Myhre
}

\begin{abstract}
This paper will argue that child and youth care is a kind of social diagram that maps the relations of children and adults. It will propose that residential care in particular, when thought of as a machinic social diagram, has certain characteristics that map its functions and capacities. Perhaps the most central of these is the fact that it is an institution that houses people. The paper will trace the roots of residential care to the model of the asylum. It will go on to explore the door or entrance to the asylum/residential care program as a significant component in the production of the machinic social diagram of residential care.
\end{abstract}

Keywords: residential care, Franco Basaglia, Foucault, Deleuze and Guattari, machinic diagram, ideology

Hans Skott-Myhre, Ph.D. is an Associate Professor of Child and Youth Studies at Brock University, 500 Glenridge Avenue, St. Catharines, Ontario, Canada, L2S 3A1.

Email: hskottmy@brocku.ca 
International Journal of Child, Youth and Family Studies (2012) 2 \& 3: 316-330

\section{Child and Youth Care as Residential Care}

Most of us who work in child and youth care have at one time or another practiced within an institution. Outside of street work (whose relationship to the institution is considerably more ambivalent) CYC is a field largely set within the confines of a building designed to house young people. Indeed, a recent read-around in the on-line site CYC-net.org included over 50 articles on residential care as a site of CYC practice. Books by Maier (1987), Durrant (1993), and Anglin (2003) have also engaged the practice and theory of residential care for children and youth. Much of this writing has focused in four major areas: the development and deployment of relationship, issues related to behavioral change, management of staff, and theories and practices related to child development.

While the encounter with children and youth within the institutional parameters of residential care is obviously significant, we might also easily expand the scope of our work beyond the residential facility to the more general field of encounters between young people and adults. Indeed, one might argue that institutional sites such as residential care are transition points in the broader set of social relations between young people and adults that involve caring for children and youth. It would even be possible to go further and suggest that residential care is but one institutional site in an array of buildings designed to contain sets of relations between young people and adults that include schools, family homes, children's psychiatric wards, and day treatment centers among others. If we were to be even more comprehensive, we might note that there are sites such as wilderness and outdoor recreational/experiential programs that have little or no buildings involved at all. I would argue, however, that all of these sites, despite their apparent differences, share a commonality of structure and purpose. To use a term from Deleuze and Guattari (1987), they compose a certain kind of machine or, in Foucault's (1979) parlance, a social diagram.

\section{Child and Youth Care as a Machinic Social Diagram}

Thinking about this diverse array of sites as a machine is premised in a view of the world as an ongoing and indeterminate set of compositions. To get a sense of this view, we might well imagine all elements of the world as made up of particles. Each particle has a certain set of capacities that only it can express. The capacity for expression in each particle is entirely unique and cannot be replicated by any other particle. At the same time, however, within that same particle, there are an infinite number of possible ways that its unique capacity can be expressed.

To use a very approximate example, let's use the color red. Red is unique in that it cannot express itself as anything other than red. It is rather specifically not blue or any other color. Nonetheless, there are an infinite number of variations of shadings of red that are possible. These shadings occur, though, through encounters with other colors, such as blue. It is through these encounters that the capacities for expressing red are enhanced and expanded. 
International Journal of Child, Youth and Family Studies (2012) 2 \& 3: 316-330

This encounter between colors constitutes a form of composition. As we have noted, each color has a unique and idiosyncratic capacity for expression. Exactly what range of capacity the color has, however, is unknown in advance. In fact the color can only be expressed in a relation with another color. Red as an expression cannot stand alone. Its capacity for redness in all its variation can only be known through collisions with other colors.

With this in mind, let's return to the realm of the world as particles. Like colors, each element of the world has capacities for expression. These capacities can only be expressed in combination with other particles. This means that the world can only come into being as a dynamic set of relations between an infinite array of particles in collision with each other.

This implies that the world is not a stable predetermined set of structures. It is instead an indeterminate composition in which no element has an a priori form or structure. Each form or structure is being produced in the moments of its collision with other forms that elicit unpredictable capacities for expression. Each of these compositions, made up of elements in chance encounter with each other, constitutes a particular form. This form is not static, but has unique capacities of its own. These capacities are of two types.

One capacity, as we have noted, is that of composition. The other is that of decomposition. Each form can compose or decompose its own structure. It can also combine with other forms to compose or decompose itself, the other form, or the structures within which it is embedded. Implied in this last statement is the recognition that there is no capacity to step outside this system of composition and decomposition. All forms, structures, particles, and capacities are mutually folded into themselves like a multidimensional kaleidoscope made of time, space, and thought.

The discrete elements of composition that occur in any given moment are what Deleuze and Guattari (1987) refer to as a machine, that is, a composition of elements which, when set in relation to one another, have the capacity to do something. All of the forms of care, when thought of as machinic, are actually sets of relations composed at both the macro and micro level. For example, each of the forms of child and youth care from street outreach, to schools, to residential treatment, form a macro machine composed of a network of practices, ideas, and physical structures.

At the broadest level, this machine produces the field of child and youth care as a global machine made up of all forms of care across the planet ${ }^{1}$. As we come in closer, the sets of relations become more specific and include particular children and adults, unique practices, forms of thought and reflection, sets of affects, as well as all the elements of the physical plant including furniture, heating and cooling systems, lighting, plants,

\footnotetext{
${ }^{1}$ This becomes increasingly clear when one notes the international composition of articles and postings on a site like CYC-net.org.
} 
International Journal of Child, Youth and Family Studies (2012) 2 \& 3: 316-330

animals, insects, food stores, and so on. All of these elements compose and are composed by their encounters with each other and form a certain kind of machine that creates definitions, boundaries, structures, rules, forms of discipline, as well as revolts, forms of resistance, lines of flight, and spaces of retreat.

When such a machine is read at the level of a given society, in a particular historical moment, it constitutes a physical mapping of social norms and expectations, as well as a distribution network for disciplinary practices and dominant ideas. This is what Foucault (1979) called a social diagram.

Child and youth care, as a social diagram, maps the relations of children and adults. It inscribes sets of values, codes of conduct, definitions of childhood and adulthood, trajectories of social competence, and deviance. It distributes these maps in the forms of codes, both linguistic and material. At the level of linguistic code, the diagram facilitates the movements of certain ideas and beliefs across all the bodies in the field of child and youth care. At the material level, the diagram enables the spread of practices and forms of discipline. That is to say, it promotes certain usages of the body and mind as preferable or ideal.

The field of child and youth care as a machinic social diagram often produces itself as apparently ahistorical. That is, it claims to simply describe its beliefs and practices in terms of either common sense or as true. When this is done, important context is removed that might help us to see the ways that certain ideas and practices are actually sites of struggle and contestation. Foucault (1971) suggests that what he calls the habits and beliefs of one's own age are products of the ongoing tension between dominant assertions of social control and the productive power of creativity and living force. Deleuze and Guattari (1987) similarly propose that all social forms are historically produced. These social forms are contingent and time limited and will eventually dissemble into something else. Such forms of thought and practice are far from being fundamentally true. They may, in fact, form a certain kind of common sense, but as Gramsci (1971) and Friere (2000) point out, such common sense is generally to the advantage of the ruling class in any given historical period.

Certainly, the institutional form of child and youth care referred to as residential care is composed of all of the elements of the machinic social diagram we have outlined above. Indeed, one might argue that it constitutes a perversely central role in the field of practice. Perverse in the sense that very few child and youth care thinkers or practitioners believe that having young people spend their childhood and youth in an institutional setting is ideal, and yet the form persists. Residential care as a machinic social diagram has certain characteristics that map its functions and capacities. Perhaps the most central of these is the fact that it is an institution that houses people. It is a system of care premised on residency. 
International Journal of Child, Youth and Family Studies (2012) 2 \& 3: 316-330

\section{Child and Youth Care and the Asylum}

The specific form of residency is premised on the model of the asylum ${ }^{2}$. The asylum might well be defined as a residence that is ostensibly specifically designed to remove certain members of society on the basis of a need for care exceeding the abilities of other social structures such as families. The diagram for the asylum was founded in pre-revolutionary France in 1656 when, within the space of several months, hundreds of Parisians were incarcerated in what had previously been a hospital for leprosy (Foucault, 1988). The social and political reasons for these actions had to do with a breakdown in social order leading to an extraordinary influx of the poor into Paris. The government, faced with a large and unhappy population of the poor, first posted archers at the city gates with orders to shoot any unemployed poor person attempting to enter the city. When this failed, the government simply began to arrest and incarcerate the poor on the basis that they could not care for themselves (Foucault, 1988).

This desperate act of incarcerating people against their will in order to care for them, by a government in crisis, was to have historical implications that resonate today. Foucault (1988) traces the evolving government rationale for incarceration. He notes the ways in which the poor were identified and classified, as both morally and mentally incapable. Instead of acknowledging a breakdown in the capacity of the government to meet the needs of its people, the poor became the scapegoats for moral and political disorder. There are two aspects of what Foucault (1988) calls the great confinement that are of particular interest in terms of what eventually emerged as residential care.

The first that Foucault proposes is the idea that poverty is a personal moral failing that may indicate an emotional or psychological disorder. Thus, poverty is not to be remediated by any substantive reallocation of wealth or resources, but by the treatment of the individual's moral, psychological, or emotional problems. Basaglia (1987) noted that the mad who inhabited the asylums well into the 20th century were disproportionately poor. Certainly, my own experience working and consulting in residential care would indicate a similar trend, which is that those incarcerated for care tend to be the children of the poor. This in and of itself might not be too surprising, as poor families and communities have fewer resources to care for children. However, what is interesting is that very few programs address the issue of poverty. Instead, as Foucault (1988) suggests, residential care continues to deal with the children of the poor as primarily in need of emotional and psychological care.

While one population that has carried forward in residential care within the diagram of the asylum is the poor, there is a second group that is of interest to us here. This second group is unmanageable youth. Donzelot (1980) tells us that one of the effects of the social disorder in France that led to the great confinement was a breakdown in the

\footnotetext{
${ }^{2}$ See Goffman (1961) Asylums for a read on the asylum as a total institution that produces what he calls "institutionalization". He argues that institutionalization socializes people into the role of passive participants in the institution or good patients. A similar argument will be made here in terms of residential care. See also Beker and Feuerstein (1991) who utilize Goffman to make a series of proposals challenging the totalizing effect of the institution in residential care for children and youth.
} 
authority of the father within the merchant class. The financial crisis of the 17th century severely strained relations between the merchant class and the ruling regime. Donzelot (1980) reports that the ruling regime gave significant control over the affairs of the family to the father. The fathers in turn provided financial and social protections to their wives and children. In exchange, the fathers provided the ruling class with sons as soldiers, merchants, and colonial functionaries.

Donzelot (1980) further explains that the financial and social crisis that led to the great confinement threw this relationship into chaos. The regime was unable to provide the fathers with the means to provide their families with social and economic stability. The sons and daughters who had lived under the absolute authority of the father began to question that relationship. In short, they began to rebel by breaking social conventions of all types. The fathers reacted by using the newly formed asylum. Using the power vested in them by the state over their children, they began to have them incarcerated as mad. In fact, this became such a prevalent practice that the asylum ran out of space to house these mad children of the merchant class. The government had to refuse orders of incarceration causing even greater crisis in social and family relations. Indeed, Donzelot argues, this may well have been a significant causal factor in the French Revolution. He notes that the first institution liberated by the revolutionary masses in Paris was the Bastille, where the political prisoners were held, but the second was the asylum that housed the children of the merchant class.

It would be hard not to note a similar trend in the current practices in residential care. One could well argue, as Paolo Virno (2004) has, that we are living in the new 17th century. The disintegrating relationship between the current capitalist ruling class and the middle class, under conditions of financial crisis and social upheaval, has eerie similarities to what we have described above. Similarly, authors such as Henry Giroux (1996) and Mike Males (1996) have noted broad claims that the children of the middle class are losing both their minds and their moral compass. In the 17th century, the ruling class managed the crisis of the poor by designated them mad and morally unfit. In today's crisis, they have instituted a proliferating array of diagnoses that allows the designation of young people in crisis as oppositionally defiant or biochemically imbalanced.

The machinic diagram of the asylum, founded in the Parisian financial crisis of 1656, has sustained itself well into our current historical period. Our current institutions of care continue to be composed of the elements of incarceration, psychological diagnosis, and moral remediation. We continue to operate on behalf of the ruling class in controlling and disciplining our own children under the guise of care, rather than addressing the actual moral and functional bankruptcy of the existing system of global capitalism. We perpetuate the machinic social diagram in our current institutions of residential care. In light of this, I would suggest that an examination of the elements of this diagram might be in order. I would like to open that analysis here with a look at one particular element: the door of the institution. 
International Journal of Child, Youth and Family Studies (2012) 2 \& 3: 316-330

\section{The Question of the Door}

Each residential care facility is comprised of an inside and an outside mediated by an entrance. This entrance is a portal to a building accessed by adults on behalf of young people who generally have little or no choice about entering themselves. In the case of young people, the subjects who enter the asylum/residential program are there either involuntarily or because they have no other viable living arrangement. Upon entering the facility, their relation to the institution is, at best, ambivalent and most often hostile or resistant (Arieli, 1997). Their allegiance is to life outside the institution and their attitudes and behaviors often reflect this.

The staff of the institution also holds an ambivalent relation to the facility. Oftentimes, their relation to the agency that runs the facility is that of subjugation. Put simply, they are at the bottom of a hierarchy of power that exercises disciplinary control on their actions and expects that they put their bodies and their thoughts at the disposal of the agency's agendas. They ostensibly enter and leave the facility freely, but for many the choice to come and go is driven by financial exigency and may not be absolutely voluntary. Their job is to integrate and transform the young people into clients of the agency's services. They are to turn the allegiances of the youth/children from the outside world to the inside of the facility. To do this, they deploy an extensive array of social technologies including using their own affective engagements with the young people to attach them to the staff and hence ultimately to the institution ${ }^{3}$.

The question of bodies, their attachments, and flow inside and outside of the institution is defined by both the physical infrastructure of the buildings, rooms, and grounds as well as by the attachments and internalizations of institutional values and regimes of discipline and control. Perhaps the object most symbolic of a body's engagement with the facility is the entryway and most specifically the door.

In what follows, I will engage the question of the door as a certain kind of mechanism or machine that produces the inside and outside of any space. A door is always a space between. It can be open or closed, opaque or clear, locked or unlocked, barred or unbarred, thick or thin. It can serve multiple purposes including keeping a hostile world outside or creating a productive space of solitude. In the service of a dominant system of control, it most often is deployed as mediation between spaces that holds the possibility of being controlled and shaped to particular purposes. The door in question within the residential facility is a physical door that can be locked to prevent those inside from gaining access to the outside. However, the door also represents the inside and the outside as a set of relations beyond any specific physicality. In this case, it comprises a very complicated set of meanings that produces multiple and, at times, contradictory inflections of the relation of inside to outside.

These meanings can be plotted on a grid composed of bodies, psychic structures, social norms, and institutional physicality. The function and quality of the door in

\footnotetext{
${ }^{3}$ Macleod (2010) notes the complexity of this role and the anxiety it produces for staff in residential care.
} 
International Journal of Child, Youth and Family Studies (2012) 2 \& 3: 316-330

question is composed of bodies; bodies on one side of the door and bodies on the other side. Some bodies can move through the space defined by the door and others may not. There are, of course, rules about which bodies can move and which cannot.

Within this space, functionaries of the institution can enter and leave by using keys provided by the institution. They cannot, however, simply enter and leave when they would like, but only in their role as staff. Within these parameters, the institution functions as an outside to all bodies within its realm. It produces the identities and functions of the staff as well as the youth. The institution not only controls the activities of the young people, but also regulates the flow of staff in and out and prescribes what they are to do and what they must not do.

\section{Staff as Functionaries of the Dominant Ideology}

The anti-psychiatrist, Franco Basaglia (1987), notes this as the way in which the staff are deployed as, "functionaries of the dominant ideology" (p. 144). He states that the way in which such staff operate within the institution is often diametrically opposed to their own political orientation outside. They become, what Basaglia references in Sartre as, "technicians of practical knowledge, whose duty is to concretely implement both ideologies and the crimes of peace that those ideologies legalize and justify” (p. 145).

Basaglia (1987) had reason to think carefully about the relation of staff to the institution and about the question of doors. In 1961, he was a young Italian psychiatrist who had become the director of an asylum in Gorizia, Italy. Although he had nearly 10 years experience as the director of a university clinic, nothing prepared him for what he would find in the back wards of his new institution.

The world of the asylum at that time was savage and brutal in both its rampant use of electroshock, psychosurgery, and hydrotherapy as well as restraint, and its complete disregard for human dignity and basic hygiene ${ }^{4}$. Deeply influenced by Sartrean phenomenology as well as the Marxist theories of Gramsci and the Frankfurt school ${ }^{5}$, Basaglia set out to dismantle the asylum in order to return what he termed subjectivity to the patients whom he felt had lost any sense of themselves through their incarceration. His methods were radical and innovative involving restructuring the lives and roles of both patients and staff. He claimed that the people incarcerated within the asylum were suffering not so much from psychiatric illness as the effects of a brutalizing socioeconomic system amplified by the institutional effects of the asylum itself (ScheperHughes \& Lovell, 1987).

While Basaglia's efforts were only partially successful at Gorizia, where he faced significant political opposition, he set the groundwork for his life's work. He left in 1977

\footnotetext{
${ }^{4}$ For a documentary account of similar conditions see Frederick Wiseman's 1967 film Titicut Follies. For a fictional account of the Italian experience, see M. T. Giordana's (2003) film, Best of Youth. For a photo essay, see Manzoli's (2004) Images of Madness, The End of Mental Hospitals.

${ }^{5}$ In particular Horkheimer, Adorno. The Trieste group also used Lukacs to advance their theoretical work. See Scheper-Hughes and Lovell (1987, 315 n 5, 8).
} 
International Journal of Child, Youth and Family Studies (2012) 2 \& 3: 316-330

and moved to Trieste where he continued his efforts at dismantling the institution. At Trieste he was very successful and in fact his model of deinstitutionalization spread across Italy resulting in national legislation that prohibited long-term institutionalization of those termed mentally ill (Scheper-Hughes \& Lovell, 1987).

Basaglia began with a problem. He had decided, upon taking directorship of the asylum, that he would unlock the back wards and allow patients freedom of movement. His problem was that they wouldn’t leave. He opened the door but,

Basaglia discovered that the open door merely reminded the patients of their confinement, and of their rejection by the world outside. Instead of taking the cue to freedom and autonomy offered by the open door, the newly liberated patients at Gorizia remained passive and imprisoned by an internalized image of the asylum. Basaglia wrote, "As long as they accept liberty as a gift from the doctor they remain submissively dominated.” (Scheper Hughes \& Lovell, 1987, pp. 18-19)

With the problem of the door, we engage the question of this essay. In what ways does the door operate, not imply as an entrance, but as an active piece of machinery that signals certain practices, beliefs, and even forms of identity? The institution, in this way, not only controls and shapes the embodied flow of staff and clients, but also shapes the ideological underpinnings of their behavior so that it might well become alien to their own stated beliefs on the outside. In shaping the ideas and beliefs of the staff and clients, the institution functions between the literal outside community and the internal relations of the facility in ways that produce even the staff as alienated from their external identities.

Take, for example, a staff member whose identity outside the institution is that of a racial minority often subject to police harassment and racial slurs. However, inside the institution they hold a supervisory role and deal with the police and white staff with the backing and authority of the institution. Once they walk in the door, they are in a position of authority and control; once they walk out the door, they are once again subjected to the racism and intolerance of the dominant social. Giving a more concrete example, a few years back I was attending a retreat with a black, male colleague where he was giving a key presentation. The retreat was set in a white suburban area, and during the lunch break my colleague took a walk whereupon he was confronted by a police car and asked what he was doing walking in that area; inside the retreat he was a member of the institution, outside he was not. Obviously, it is the physical edifice that constitutes the physicality of both inside and outside. At the same time, it is also the ultimate mediation of all kinds of flow throughout its interior.

All bodies within the physical plant of the agency must function in relation to the institution itself. All bodies have the institution etched across their every movement. It is critical to note here that they are not the institution, even though they may carry it with them in all their interactions including outside the gates of the physical plant, and in spite of the fact they may begin to see all other bodies in their world in the terms of the 
International Journal of Child, Youth and Family Studies (2012) 2 \& 3: 316-330

institutional grid, as emotionally healthy or sick, developmentally appropriate, or oppositional and defiant.

Basaglia (1987) argued that the institution remains estranged from them. Even as the institution enters the bodily flow of subjects and directs it across its face, it remains strange and alien: always outside. The functionaries of the institutions often want to belong to it and may even claim membership in it or mistake its derived power for their own, but it is not so. The institution is separate and strange. Even though it may masquerade as familiar, its familiarity is to be found in the rituals of its designated orders. Its habits, inscriptions, proscriptions, and prescriptions may be known, but not the institution itself. The institution is, in its estrangement, invisible even in its entry into life.

\section{Doors, Rituals and Technicians of Practical Knowledge}

The door, as a manifestation of the unknowable institution, signals a series of rituals that shapes the flow of bodies across its face. Through the mixture of bodies and rituals, we can infer that psychic structures associated with the embodied subject are also in play here. It is in the belief in the rituals of the door that both the functionaries and the clients enter into the space of institutional ideology. This is what Basaglia (1987) referred to when he describes the staff as technicians of practical knowledge. The phrase is designed to infer a cold and even clinical sense of the work as a technical application. Certainly, we can see edges of this in our work in the worst practices of evidence-based practice or in the blind application of a new technique or strategy of behavioral modification. These practices and techniques are often offered to us as practical knowledge; practical, as opposed to the supposedly unprofessional, impractical, and complex sets of feelings and thoughts we might have in relation to young people left to our own devices.

Basaglia (1987) goes further to describe this technical application of practical knowledge by stating that the duty of these technicians is to "concretely implement . . . ideologies". Here he is using a term from Althusser (2001) that refers to a system of ideas and beliefs that supports the interests of a particular class. In particular, Basaglia is suggesting that once the staff enters through the doors of the institution, they begin to become social technicians. In this role, they take on the task of finding ways to concretely put into practice the beliefs and ideas of the ruling class.

If Basaglia is correct, then it would behoove us as staff who work in residential care institutions, to closely examine the dominant ideas and beliefs we have been taught or have come to believe are simply common sense. For example, we might ask, in what ways does the commonly held concept of development support the interests of the ruling class?

Basaglia (1987) goes one step further and states that the entry into the institution and the adoption of the role of social technician also requires that we commit what he calls, "the crimes of peace that those ideologies legalize and justify". Here, he is juxtaposing the crimes of peace to the category of war crimes. However, he is suggesting 
International Journal of Child, Youth and Family Studies (2012) 2 \& 3: 316-330

that peacetime is no guarantor of humane and ethical treatment. Like Foucault (1979) who has proposed that war continues in a different form once peace is declared, Basaglia is suggesting that apparent domestic normalcy can obscure subtle yet horrendous violations of dignity and sovereignty. Such practices will be carried out under the auspices of ideology masquerading as common sense. The range and scope of such practices and rituals is often determined by a door.

Doors indeed have often opened onto spaces filled with ritual, from churches to homes, schools, factories, barracks, camps, and prisons. The door is a critical element in the production of spaces of containment under the regimes of the disciplinary society. The subjects, as they pass through the door, are directed into the rituals associated with certain spaces such as: cooking, cleaning, running machinery, beating prisoners, reading books, writing on chalkboards, committing genocide, vacuuming, water-boarding, praying, fucking, and confessing. Indeed, each door signals the rituals of space with its expectations of safety or cruelty for each subject depending on whether they enter the kitchen, the classroom, the cell, the concentration camp, the bedroom, the therapist's office, or the factory.

Importantly, it is in the violation of these rituals that the possibilities for eluding control and constituting alternate subjectivities are produced. That is to say, that the events within the institution are both composed of rules and regulations, as well as behavior that does not make sense within those rules. The "mad" things that go on in the facility signal that there is an outside to that logic that cannot be fully contained by the rules and proscriptions. There is a surplus of behavior, as violation, that signals an opening in the hegemonic ideological structure of the institution.

In final analysis, the violations are not always sanguine. They can be violations of immense cruelty and trauma as well as the violations comprised of small bids for freedom and resistance. The psychic structure of the institution, produced as the simulacrum of singularity we call the individual, is premised always in relation to the doors and rituals of contained space. Even the individual self is comprised in this way. The psychic structure of residential treatment attempts to open a door between the self as unconscious and conscious, rational and irrational, speakable and unspeakable selves. This door is also comprised of a set of rituals and simulacra of relations through which the child and youth care worker produces a space in which the ritualized relations of family life, with its doorways and rituals, can be re-entered and replicated. Within this, there are both possibilities of producing the self as compliant within the confines of the dominant social, as well as creating an avenue of resistance and creative flight. What are we to say of the possibility of the spaces produced beyond effective discipline, signaled by an engagement with creative deviance?

\section{Contradictions of Care}

Critical here is the notion of contradiction. The institution produces itself as seamless ideologically and structurally; everything that occurs is rational and ideologically justifiable. As we have pointed out, this seamless space can only sustain 
International Journal of Child, Youth and Family Studies (2012) 2 \& 3: 316-330

itself as an enclosure that circulates highly ritualized flows. Any violation, however slight, must be caught and sanctioned, which means for a young person in care: diagnosed and treated; and for a staff member: corrected through training or supervision. The moment at which this seamless architecture fails to conceal the gap between its ideological facade and the actuality of its daily material function, a deviant line is opened. It is in this space of contradiction that new possibilities can be nurtured.

Inevitably though, it is quite clear that such openings are temporary and that the dominant structures of the social will put all its resources to reconfiguring its architecture to recover its seamless form. The source of the contradiction, however, is not to be found in ideological production, but in the subject that has been excluded. Such a subject must remain excluded in order to provide both the justification for the institution itself and the dominant social ideology that it protects. The vehicle for the production of this exclusion is the relation between the community and the institution. Community, in this sense, is that community built on a framework of exclusion. The children and youth in care are produced as outside the social by the very aspect of their confinement. Their confinement signals an absence. They are missing, but we are not allowed to miss them; at least not publicly. They are where they are for a reason. They cause us trouble because when they are with us in community, they produce holes in the fabric of our lives, our habits, our comforts, and our commonality. Their difference must be secluded away and not missed except in the solitude of those who know they also do not really belong to the commonality of the social.

Unfortunately, the reason that they are troubling is because they illustrate the bare fact that the social is incapable of caring for its members. Basaglia (1987) points out, that in a functioning social, those members who are experiencing difficulties are cared for within their families, homes, and workplaces. These spaces are provided, or are able to provide for themselves, the necessary resources to compassionately care for those who are suffering. Obviously, this would require a radical re-orientation of resources and a reallocation of time based on people's actual needs rather than the needs of capitalism for profit.

The entire system of care for young people is the demonstration of the failure of the dominant social. Nonetheless, the liberal capitalist state promises that it can meet all human need through the ever-expanding creation of wealth and technology. If everyone will wait their turn and work hard, all needs and desires will be met. If someone is failing to achieve their potential as a citizen of capitalist society, they must not interfere with the work of the rest of us. They will be "cared for" by institutions specifically designed to "help" them.

Each of these institutions has a door that will hide their suffering from view. It is clear, though, that each of the inmates knows that that door simply symbolizes their rejection by the dominant social and holds little possibility of actual care. Even if an inmate is released into the outside world, they know they must never, ever, show any trace of their suffering or they will be shunned and excluded. They must assimilate into 
the world of capitalist relations and its sets of alienated relations. So, each in her turn carries the door with them even into the outside world.

\section{Destroying the Logic of the Door}

The question then becomes: How to destroy the logic of the door? One opening for accomplishing this is through the concepts of contradiction and antagonism. It is crucial, as Foucault (1971) has pointed out, that the apparently benign institutions of civil society be stripped of their benevolent veneer to expose their raw disciplinary force. To do this within the kind of institutional machinery we have elaborated here, the doors produced by the dominant social to their own ends, must be removed. In other words, the barriers between the forces of the various bodies within the institution must be cast aside.

This is, we should note, neither a liberal project of reform, with all of its mediated safety, nor simply a humanitarian project, which would make the institution a less ugly or painful place. What we must aim to do is to destroy the institution itself so as to release the life it contains into the social. Correspondingly, this flow of missing bodies out of the institution would release the force of the bodies embedded within the carapace of civil society by their collision with the bodies from the inside. In short, this would be a revolutionary project designed, not simply to free those within the institution, but also those on the outside; to join those bodies together through the exposure of the contradictions and antagonisms made obvious in the exposure of the machinery of the institution itself. 
International Journal of Child, Youth and Family Studies (2012) 2 \& 3: 316-330

\section{References}

Althusser, L. (2001). Lenin and philosophy and other essays. New York: Monthly Review Press.

Anglin, J. (2003). Pain, normality and the struggle for congruence: Reinterpreting residential care for children and youth. New York: Haworth.

Arieli, M. (1997). The occupational experience of residential child and youth care workers: Caring and its discontents. Child \& Youth Services, 18(2), xv-119.

Basaglia, F. (1987). Peace time crimes: Technicians of practical knowledge. In A. Lovell \& N. Scheper-Hughes (Eds.), Psychiatry inside out: Selected writings of Franco Basaglia (pp. 143-160). New York: Columbia University Press.

Beker, J., \& Feuerstein, R. (1991). Towards a common denominator in effective group care programming: The concept of the modifying environment. Journal of Child and Youth Care Work, 7, 22-24.

Deleuze, G., \& Guattari, F. (1987). A thousand plateaus: Capitalism and schizophrenia. Minneapolis: University of Minnesota Press.

Donzelot, J. (1980). The policing of families. London: Hutchinson.

Durrant, M. (1993). Residential treatment: A cooperative, competency-based approach to therapy and program design. New York: W. W. Norton.

Foucault, M. (1971). Human nature: Justice vs. power. Retrieved June 14, 2011 from http://www.chomsky.info/debates/1971xxxx.htm

Foucault, M. (1979). Discipline and punish: The birth of the prison. New York: Vintage Books.

Foucault, M. (1988). Madness and civilization: A history of insanity in the age of reason. New York: Vintage Books.

Freire, P. (2000). Pedagogy of the oppressed. New York: Continuum.

Giordana, M. T. (Director). (2003). The best of youth (La meglio gioventù) [Motion picture]. Italy: Rai Fiction.

Giroux, H. A. (1996). White panic and the racial coding of violence. In H. A. Giroux (Ed.), Fugitive cultures: Race, violence and youth (pp. 27-54). New York: Routledge. 
International Journal of Child, Youth and Family Studies (2012) 2 \& 3: 316-330

Goffman, E. (1961). Asylums: Essays on the social situations of mental patients and other inmates. Oxford, UK: Doubleday (Anchor).

Gramsci, A. (1971). Selections from the prison notebooks of Antonio Gramsci (G. N. Smith, Ed.; Q. Hoare, Trans.). New York: International Publishers.

Macleod, I. (2010). Are you managing? The effective management of anxiety in residential settings. Scottish Journal of Residential Child Care, 9(1), 43-51.

Maier, H. (1987). Developmental group care of children and youth: Concepts and practice. New York: The Haworth Press.

Males, M. (1996). Disowning the future. New designs for youth development, 12(4), $10-14$.

Manzoli, F. (2004, June). Images of madness. The end of mental hospitals illustrated through photographs. Journal of Science Communication, 3(2).

Scheper-Hughes, N., \& Lovell, A. (1987). Introduction: The Utopia of reality. In A. Lovell \& N. Scheper-Hughes (Eds.), Psychiatry inside out: Selected writings of Franco Basaglia (pp. 1-50). New York: Columbia University Press.

Virno, P. (2004). A grammar of the multitude. (I. Bertolettoi, J. Cascaito, \& A. Casson, Trans.) New York: Semiotext(e).

Wiseman, F. (Director). (1967). Titicut follies [Motion picture]. United States: Zipporah Films. 